\title{
The Use of Project Activity in Teaching Mathematics
}

\author{
Nadezhda V. Telegina ${ }^{1}$, Sergey E. Drovosekov ${ }^{2}$, Dinara G. Vasbieva ${ }^{3}$, Valeria L. Zakharova ${ }^{4}$ \\ ${ }^{1}$ Kazan (Volga region) Federal University, Kazan, RUSSIA \\ 2 Vyatka State University, Kirov, RUSSIA \\ ${ }^{3}$ Financial University under the Government of the Russian Federation, Moscow, RUSSIA \\ ${ }^{4}$ I.M. Sechenov First Moscow Medical University (Sechenov University), Moscow, RUSSIA
}

Received 4 November 2018 - Revised 22 February 2019 - Accepted 5 March 2019

\begin{abstract}
The relevance of this study is due to the ever-growing demands that the rapidly developing society makes to the education system, according to which the priority factor in the development of students is the ability to independently plan their activities to acquire the necessary knowledge and skills during joint creative and cognitive activity. It is confirmed that it is during the implementation of projects that it is possible to reveal the potential of students in self-realization, interaction with others and development of critical thinking. The goal of this article is to study the theoretically grounded and practically proven effectiveness of the use of project-based training in the study of mathematics by students of the secondary school. The main method of this research is a pedagogical experiment, as well as observation, a quantitative method and statistical processing. In the process of teaching mathematics, the specifics of project training as a student-centered method aimed at improving analytical and creative skills were taken into account. Gradual methodological methods for the organization of the project activity of students are developed. In the course of testing, model images of lessons were obtained, substantive content was determined and specified, thematic lines of the project activity in teaching mathematics in basic school were built, and the use of variable forms of the project activity was justified. The peculiarities of the author's approach to the study of the features of project-based learning are the allocation of special criteria for project assessment; comparative analysis of approaches of foreign and domestic scientific schools to the project activity. The study revealed the effectiveness of project-based training in teaching mathematics. The materials of the article are valuable for primary and secondary school teachers, teachers of secondary vocational and higher educational institutions. The use of the project activity in teaching mathematics in basic school contributes to increasing the level of motivation to study the most difficult topics of the course, ensures the implementation of an integrated approach to the study of natural sciences.
\end{abstract}

Keywords: the project activity, project training, project method, project, teaching methods, mathematics education

\section{INTRODUCTION}

\section{The Relevance of the Problem}

Recent changes in society have formed a new social order for the activities of the educational system, which is characterized by the fact that the very ability to extract information, work with information, process and cut off the excess and isolate the essential, is becoming more significant than the knowledge itself (Anderson, 2017; Faleeva et al., 2017; Hoa \& Valco, 2018; Khusainova et al., 2018; Velieva et al., 2018). As a result of these trends, the

(C) 2019 by the authors; licensee Modestum Ltd., UK. This article is an open access article distributed under the terms and conditions of the Creative Commons Attribution License (http://creativecommons.org/licenses/by/4.0/). \nadya-telegina@yandex.ru $\boldsymbol{\Delta}$ se_drovosekov@vyatsu.ru (*Correspondence) $\square$ dinara-va@list.ru 


\section{Contribution of this paper to the literature}

- The study differentiates the project assessment criteria within the project team, divided according to creative and cognitive abilities, which contributes to more effective implementation of the project task

- This work systematizes didactic and pedagogical approaches to project training in mathematics in basic school. System analysis of theoretical works allowed to propose a number of effective methods of project training in the framework of the topic "Divisibility of numbers"

individuality of the student, his/her ability to self-determination and self-realization, to make independent decisions and bring them to performance, to analyze own activities, to interact with others and plan own activities prevail now (Duke, Halvorsen \& Strachan, 2016; Tyurikov et al., 2018; Vinogradova et al., 2018).

The most important element of the educational system is mathematics education. The value of mathematical science in the world is increasing every year, that is why a high level of mathematics education is the key to success in all areas of the activity. At the same time, some decrease in the level of mathematical training of students has recently been noted. The negative attitude towards this science is formed in students in school, which leads to unwillingness to continue to study this difficult subject and, as a result, to a low level of mathematical training not only of schoolchildren, but also of students (Folomkin \& Voronina, 2017; Galushkin, 2015; Kostrova, 2011).

A lot of various scientific information in different fields, its dynamic change makes it impossible within the school curriculum to study all subjects, including mathematics, in full. The use of the project activity in teaching mathematics allows one to go beyond the established traditional approaches to learning, to work in a mode that encourages to search for new information, independent productive activities aimed at developing the student's critical and creative thinking (Iksanova, 2015).

\section{Goals and Tasks of the Study}

The goal of this article is to study the theoretically grounded and practically proven effectiveness of the use of project-based training in the study of mathematics by students of the secondary level of education.

Achieving the goal of the study required the solution of the following main tasks: analysis of the scientific, methodological and psychological-pedagogical literature on the research problem; the study of the features of the application of the project method in teaching students in the secondary school; identifying the specifics of the cognitive actions of students in preparing and conducting the project activity when studying mathematics; development and implementation of the project in practice; drawing up criteria for assessing the effectiveness of the project activity.

\section{LITERATURE REVIEW}

In Russia the ideas of project education arise almost in parallel with the developments of foreign teachers at the beginning of the 20th century. In 1905, under the leadership of the Russian scientist Shatsky (1980) there was a small group of specialists who attempted to use project methods in teaching practice.

Later, in the process of development and establishment of education in the new socio-economic formation, these ideas became quite widely, but not sufficiently thoughtfully and consistently, introduced into the school, and by the decision of the Central Committee of the All-Union Communist Party of the Bolsheviks in 1931 the project method was condemned. Since then, no serious attempts to revive this method in practice have been made in Russia (Ischenko, 2015).

Although the project method was prohibited, some of its elements were borrowed and interpreted at the very beginning of its use.

- labour school - identifying the individual characteristics of the child, introduction of them into labour activity.

- $\quad$ the method of educational research (the 1920s) - with the help of the teacher to explore already known facts on theory and practice.

studio work - the superiority of independent work and study of the material by a separate group, in the laboratory, without a clearly defined timetable in the presence of the teacher.

- $\quad$ complex method (1923) - the unsystematic study of subjects, raising central topics, practical orientation.

- link method - the division of work in the children's team when studying a particular topic and the organization of their independent work.

- $\quad$ summer School (1931)- the acquisition of labour skills of polytechnic education and the development of practical skills (Kalashnikov, 1926). 
At the present time the method of projects is becoming increasingly popular, which is reflected in the scientific and educational researches of Polat et al. (2002), Vinogradova (2003), Pakhomova (2005). These authors note that project training allows students to develop cognitive skills, independently acquire knowledge, develop research skills and analytical thinking in the process of active creative and educational activities.

According to Shchurkova (2005) the method of projects always involves solving a problem that supposes, on the one hand, the use of various methods, and on the other hand, integration of knowledge and skills from various fields of science, technology, and creative fields. Work on the project method involves not only the presence and awareness of the problem, but also the process of its disclosure, solution, which includes clear planning of actions, the existence of a plan or a hypothesis to solve this problem, a clear distribution of roles (if group work is meant), that is tasks for each participant upon condition of close interaction. The results of completed projects should be, as they say, "tangible", substantive, that is, if this is a theoretical problem, then it's a concrete solution, if a practical one, the result is concrete and practical, ready for use.

Polat et al. (2002) focuses on the project as a way to achieve the didactic goal through the detailed development of a problem (technology), which should be completed with a realistic and tangible practical result ... to achieve this purpose it is necessary to learn children and adults to think independently, to find and solve problems, using knowledge from other areas, skills to predict the results and possible consequences of different solutions, skills to infer cause-and-effect relationships.

After analyzing the works of domestic authors on project training, it should be noted that project teaching is not used in modern pedagogy instead of systematic subject teaching, but along with it as a component of the education system. In addition, the project method corresponds to one of the main tasks of the school, which is not only to give students knowledge, but also to awaken personal motive, instill an interest in learning, a desire for self-improvement and prepare students for life in modern society (Zamoshnikova, 2006).

It is believed that the method of projects originated in the United States in the second half of the nineteenth century and its origins are connected with the research of the American philosopher and teacher Dewey and Dewey (1922). The basic idea laid down in the method by the author is that learning on an active basis through the student's purposeful activity should be correlated with the student's personal interest precisely in this knowledge. According to the concept of Dewey and Dewey (1922), learning is reduced to labour and play activities, where the child's action is an instrument of his/her knowledge through personal discovery and is a way of realizing the truth. The result of this training must be skills of thinking. The thinking skills were understood as the ability to learn (Dewey \& Dewey, 1922).

Kilpatrick (1925) and Collings (1926) also contributed to the development of the project method. According to E. Collings (1926), the main idea was to gain knowledge when working on projects, the main thing in this work was the independent activity of children, which interested them. Taking into account the personal characteristics of each child, a motive to acquire knowledge through independent work was created (Collings, 1926).

Berthier, a french educator, widely used this method in elementary school. In schools and kindergartens, children watched, wrote, read, sculpted, painted only what was related to a particular topic, and the teachers did not give the children new knowledge, the children themselves extracted it in the process of independent activity. The teacher only helped and consulted children (Ivanov \& Jordanian, 1930).

In the late 70s and the early 80s of the 20th century, the projectivity began in Great Britain, in which two areas, humanitarian-artistic and scientific-technical, united. In 1987, the School Without Walls appeared in the USA, where alternative education is used. The activity of the school was based on the project method and productive learning (Dewey, 2000).

At the present stage of development of education, the project activity is discussed in researchers from around the world, among them there are works of Gomez-Pablos (2017), Khan et al. (2015), Lam et al. (2010), Aronson and Laughter (2016), Kai Wan Chua (2017), and others. The project method as it is used today inherited only a number of initial features: consideration of the interests of students in the distribution of assignments within the project group, the specific features of student activities and teacher functions at different stages of joint activities (Celuch, Bourdeau \& Smothers, 2014), and the humanistic approach is the basis of the learning process (Ambrozy, Valčo \& Bhattarai, 2017; Laio, Hausmann \& Bezerra, 2018). Heywood (2006) considers the project activity along with problem-based learning.

\section{MATERIALS AND METHODS}

\section{Theoretical, Empirical and Statistical Methods}

To confirm the hypothesis of the study both theoretical and empirical research methods were used: 
- $\quad$ theoretical - review and theoretical analysis of psychological, educational, mathematical and methodical literature on the research problem; the study of educational and teaching materials, educational standards, school programs; the study of materials and publications on the problem; the method of meaningful generalization;

- empirical - the ascertaining and formative pedagogical experiment to determine the effectiveness of using the project method, questioning, testing, analyzing the results of experimental work, monitoring the students' activities, interviewing, statistical processing of the results of experimental work.

\section{Stages of the Study}

The study was conducted in three stages:

The first stage included the selection and study of scientific, pedagogical and methodological literature on the research topic; setting study goals and tasks, the formation of the structure, planning and forecasting the results. By testing, questioning and pedagogical observation, preliminary work was carried out to identify the students' knowledge and skills in mathematics, the level of general psychological and pedagogical characteristics, cognitive abilities and individual characteristics.

The second stage of the study is the main. At this stage, the analysis of the educational program and the teaching materials was made; the plan of the students' project activities in mastering the topic "Divisibility of Numbers" was worked out.

The educational experiment was conducted in the grade 6 of the secondary school, on the basis of which the experimental site was created the experiment involved 79 people.

The third stage was final and included the quantitative and qualitative analysis of the results of the experiment, synthesis and final conclusions based on the data obtained; the approbation of the research topic was carried out in scientific publications and speeches at conferences.

\section{Assessment Criteria}

The most complex and least developed component of the project method is the criteria for assessing the project activity, without which it is impossible to assess the effectiveness of any method. In the proposed methodology for assessing the project activity, the specific properties and qualities of the student's personality are assessed through their external manifestations in the course of the project and the defense of the project. Therefore, when developing criteria for assessing the students' project activity, its various aspects are considered and each has its own set of criteria (Nagel, 2014).

In turn, the aspects of the assessment correspond to the objects of the assessment:

- the product (the materialized result) - the product, the performance, the stand, etc.

- the process (the project implementation work) - the defense of the project, explanatory note; video series (sketches, diagrams, drawings, graphics, layouts, etc.)

- the design of the project - explanatory note, video series

- the defense of the project - the project defending process, student/speaker behavior

- management - project materials, the questionnaire of self-assessment of the teacher as a leader, the teacher's answers to the questions.

Based on the aspects and objects of the assessment, the following assessment criteria were developed, which can be decomposed into three components of the quality of education, as well as three levels of competence formation: 2 - above average, 1 - average, 0 - below average.

1. The objective-informational component (the maximum value is 6):

- knowledge of basic terms and factual material on the project topic

- knowledge of existing points of views (approaches) to the problem and ways to solve it

- knowledge of information sources

2. The activity-communicative component (the maximum value is 14):

- the ability to identify the problem and justify its relevance

- the ability to formulate the goal, tasks

- the ability to compare, summarize and draw conclusions

- the ability to identify cause-and-effect relationships, give arguments and examples

- the ability to correlate the result (the final product) with the goal

- the ability to find the required information in various sources

- the ability to speak propely, emotionally, freeely

3. The value-orientation component (the maximum value is 8 ): 
Table 1. Forming groups

\begin{tabular}{lccccc}
\hline Project name & Analysts & Experimentalists & Illustrators & Investigators & Historians \\
\hline $\begin{array}{l}\text { 1. Exhibition, collage } \\
\text { 2. Dramatization, theatrical }\end{array}$ & - & - & 25 students & - & - \\
performance & & - & - & - & 17 students \\
$\begin{array}{l}\text { 3. Broadcast, interview, } \\
\text { message }\end{array}$ & 7 students & - & - & - & - \\
4 Wall newspaper, crossword, & - & - & - & 21 students & - \\
$\begin{array}{l}\text { correspondence, story, report } \\
\text { 5. Role play }\end{array}$ & - & 9 students & - & - & - \\
\hline
\end{tabular}

- understanding the relevance of the topic and the practical significance of the work

- the expression of own position, its justification

- the ability to assess the accuracy of the received information

- the ability to effectively organize the individual informational and temporary space.

The score "satisfactory": from 12 to 17 points (42\%). The score "good": from 18 to 24 points (65\%). The score "excellent": from 25 to 28 points (90\%). The maximum possible number of points: 28

In the final assessment of the educational process, the student must clearly see: what his/her successes in mastering the educational material in general were; at what level he/she learnt it; what his/her abilities and skills are; what the assessment of his/her creative activity is; the extent to which he/she is able to show his/her personal attitude to the material being studied (Atamanova et al., 2018). Jurdak (2009) in his study considers that an important role belongs to assessing the competence of the teacher who is able to organize the work of students with different academic skills and different levels of motivation, and Ottmar et al. (2015) points out the need for additional training of teachers in new methods and techniques for more effective student learning.

\section{The Course and Description of the Experiment}

The analysis of textbooks in mathematics showed that students are trained according to the educationalmethodical set "Mathematics. Grade 6, the authors Vilenkin et al. (2013). In this study set, the project activity is not singled out separately, although there are a number of creative or practical tasks aimed at group work or work in pairs, and in the end of the section there is a historical or educational background designed to deepen students' knowledge. The author of the presented study, based on the proposed material, developed and experimentally implemented the project on the topic "Divisibility of numbers."

The students' project activity was organized in accordance with the following stages:

1. The organizational stage - familiarizing students with the specifics of the project activity, the division into groups.

2. The stage of goal setting - setting goals, familiarization with the topic.

3. The preparatory stage - drawing up the work plan for the project, the distribution of functionality within the groups.

4. The practical stage - finding information, preparing the result of the project work;

5. The presentation stage - presenting and defending the project in the class.

6. The final stage - the assessment of the results of the project activity.

\section{RESULTS}

\section{The Organizational Stage}

At this stage, the students get to know the specifics of the project activity. During this stage, the students are divided into groups. There are 5 groups: analysts, experimentalists, illustrators, investigators, historians. The division into the groups is based on the differentiated approach. The strongest students are united in the groups "analysts" and "investigators".

The joint acquisition of knowledge in the independent learning process makes it possible to focus on forming students' relations with each other, develops the ability to listen and understand, provide support, and make contacts (Christensen, 2016; Pedro \& Kinloch, 2017).

\section{The Stage of Goal Setting}

This stage is aimed at formulating the topic and goals of the activity. Goal setting is highlighting the goal with the help of the teacher. 
Table 2. Choosing the project topic

\begin{tabular}{|c|c|c|c|}
\hline Project Name & Contents & Leading Activity & Notes \\
\hline Divisibility of numbers & $\begin{array}{l}\text { Inform students about the general picture of } \S 1 \\
\text { Divisibility of numbers by topics: } \\
\text { 1. Factors and multiples } \\
\text { 2. Criteria for divisibility by } 10,5 \text { and } 2 \\
\text { 3. Criteria for divisibility by } 9 \text { and } 3 \\
\text { 4. Prime and composite numbers } \\
\text { 5. Prime factor decomposition } \\
\text { 6. The greatest common factor } \\
\text { 7. Relative primes } \\
\text { 8. The lowest common multiple }\end{array}$ & Class discussion & $\begin{array}{l}\text { The students are asked to } \\
\text { answer the question: } \\
\text { Is it possible to divide } \\
\text { everything? }\end{array}$ \\
\hline
\end{tabular}

Table 3. Project tasks

\begin{tabular}{lll}
\hline Project goal & Tasks & Leading Activity \\
\hline Mastering the knowledge and & 1. To study the historical information on this topic. & Class discussion \\
skills on the topic "Divisibility & 2. To systematize definitions and rules. & \\
of numbers" & 3. To systematize the tasks on this topic. & \\
& 4. To make a product that has practical significance. & \\
\hline
\end{tabular}

Table 4. Work planning

\begin{tabular}{llll}
\hline Group & Tasks and forms of work & Leading Activity & Deadline \\
\hline Analysts & Simple and composite numbers. Interview & Group work, & Final class on the topic \\
Experimentalists & We collect a New Year's gift. Role-play & individual work & \\
Illustrators & Photo studio. Collage & & \\
Investigators & Criteria of divisibility. Math Crossword & & \\
Historians & Mathematics of antiquity. Dramatization & & \\
\hline
\end{tabular}

Table 5. Work on the project

\begin{tabular}{|c|c|c|c|}
\hline Name of the mini-project & Tasks & Leading Activity & Notes \\
\hline $\begin{array}{l}\text { Simple and composite numbers } \\
\text { We collect a New Year's gift } \\
\text { Photo studio } \\
\text { Criteria of divisibility } \\
\text { Mathematics of antiquity. }\end{array}$ & $\begin{array}{l}\text { Independent work on projects, } \\
\text { teacher's consulting work }\end{array}$ & $\begin{array}{l}\text { Group work, } \\
\text { individual work }\end{array}$ & $\begin{array}{l}\text { At each lesson, the leaders of the } \\
\text { groups present a brief overview of } \\
\text { the project, and recommendations } \\
\text { together with the participants of } \\
\text { other groups are given. }\end{array}$ \\
\hline
\end{tabular}

\section{The Preparatory Stage}

The project development is an action plan to achieve the goal. In the course of this work, a plan of activities of project development is drawn up. In further lessons, this plan is only adjusted if necessary. Further, the main sections of the project are defined. Here it is necessary to clarify that design is considered as the development of a specific topic, the result of which is a certain result.

The functions of each project participant within each group were distributed and the leaders responsible for the work of the group as a whole were identified.

\section{The Practical Stage}

It is the stage of the project activity itself. Implementation of the project (specific practical activity, or a number of practical steps to the goal). The work is carried out in groups. Moreover, the work can be differently organized. Each section is developed by each group in turn. Then the result of the design of each section will consist of intermediate products of the activities of the groups. This form of organization is convenient in the first lessons of the cycle, when students are taught and the teacher's leadership is needed. In the future, it is possible for each group to entrust the development of its section and thereby increase the degree of independence of the children. At this stage, the role participation of students in the project is very important. It is here that each student must contribute in accordance with the chosen role (Tarasova, 2015). At this stage, students actively use Internet resources not only to search for information, but also for interaction, cooperation, because the level of development of modern interactive tools allows you to work on a project virtually (Larson, Leung \& Mullane, 2017). 
Table 6. Project presentation

\begin{tabular}{llll}
\hline Name of the project & Tasks & Leading Activity Notes \\
\hline Simple and composite numbers & 1. Presentation of the results of the project activity & Group work & The students present \\
$\begin{array}{l}\text { We collect a New Year's gift } \\
\text { Photo studio }\end{array}$ & 2. Asessment, analysis & the project in class. \\
$\begin{array}{l}\text { Criteria of divisibility } \\
\text { Mathematics of antiquity }\end{array}$ & & \\
\hline
\end{tabular}

Table 7. Project assessment

\begin{tabular}{|c|c|c|c|c|c|}
\hline Assessment criteria & Analysts & Experimentalists & Illustrators & Investigators & Historians \\
\hline $\begin{array}{l}\text { 1. Knowledge: } \\
\text { - key terms and factual material on the project topic }\end{array}$ & 2 & 2 & 1 & 1 & 2 \\
\hline $\begin{array}{l}\text { - existing points of view (approaches) to the problem and } \\
\text { ways to solve it }\end{array}$ & 2 & 2 & 2 & 2 & 2 \\
\hline - sources of information & 2 & 2 & 2 & 2 & 2 \\
\hline $\begin{array}{l}\text { 2. Skills: } \\
\text { - highlight the problem and justify its relevance }\end{array}$ & 2 & 2 & 2 & 2 & 2 \\
\hline - formulate a goal, tasks & 1 & 1 & 2 & 1 & 2 \\
\hline - compare, match, summarize and draw conclusions & 2 & 2 & 2 & 2 & 2 \\
\hline $\begin{array}{l}\text { - identify cause-effect relationships, give arguments and } \\
\text { illustrate with examples }\end{array}$ & 1 & 1 & 2 & 1 & 1 \\
\hline - correlate the result (final product) with the goal & 2 & 2 & 2 & 2 & 2 \\
\hline - find the required information in various sources & 2 & 2 & 2 & 2 & 2 \\
\hline The ability to speak properly, emotionally, freely & 2 & 1 & 2 & 2 & 2 \\
\hline $\begin{array}{l}\text { 3. Understanding the relevance of the topic and the } \\
\text { practical significance of the work }\end{array}$ & 2 & 2 & 2 & 2 & 2 \\
\hline Expression of own position, its justification & 1 & 1 & 1 & 2 & 2 \\
\hline $\begin{array}{l}\text { The ability to assess the reliability of the received } \\
\text { information }\end{array}$ & 2 & 2 & 2 & 2 & 2 \\
\hline $\begin{array}{l}\text { The ability to effectively organize individual information } \\
\text { and temporary space }\end{array}$ & 2 & 1 & 2 & 1 & 2 \\
\hline Total & 25 & 23 & 26 & 24 & 27 \\
\hline
\end{tabular}

\section{The Presentation Stage}

The presentation stage is required to demonstrate the results to the student. Competent presentation of the final product in accordance with all requirements is the most advantageous and makes the most favorable impression (Cowell, 2017). On the other hand, although at first glance, it seems that the work was aimed at making a certain product, but the result of the project activity is primarily the process itself, that is, how the project participants worked in groups, realizing themselves, how they showed their independence what skills and abilities they mastered.

If we consider this issue in this vein, then the result of the work on the project is the found way to solve its problem. According to Pakhomova (2005) "a training project differs from just a collectively prepared event or group work with the presentation of visual results, it demonstrates the main result of the work on the project - analysis of activities and presentation of a way to solve a project problem" (Pakhomova, 2005).

The presentation of educational projects was carried out in accordance with the selected sections on the general topic "Criteria for divisibility". The group with the conditional name "analysts" presented a media presentation in the form of a news program with interview elements, the children came up with the name of the program and conveyed the atmosphere of a journalistic TV show, the "experimentalists" using role-playing game showed how the rules of division work in practice. "Illustrators" for demonstrating mathematical rules showed a collage with photographs on various scales and showed how the frame sizes of photographic films correlate when printed. " Investigators " less creatively approached the task, presented a crossword puzzle, but it was very complete and detailed, covering almost all the terms of the topic. The most impressive was the "Historians'" project, which showed a dramatization about the mathematicians of antiquity.

\section{The Final Stage}

It is a self-analysis of the project activity. During self-analysis, students consider the positive and negative aspects of their activities. There is a summing up of the work as a whole. 
Using the project method allowed to change the approach to teaching mathematics. It should be noted that students not only acquired the necessary knowledge on the topic, but also improved their communication and research skills, and also realized how learning relates to practice. Moreover, many students managed to realize their creative potential, to try their hand at various professional roles (an actor, journalist, photo master, etc.). It should be taken into consideration that the result of a successful project activity is coordinated work at all stages, that is, not only the final product, but also the process of working on a project have value (Reid \& Garson, 2016).

While working on the project, one should not lose sight of the fact that the acquisition of mathematical knowledge and skills is of top priority. In his study, Sleep (2012) stresses the need to adhere to the mathematical line, regardless of the forms and methods of work, the main task in the lessons of mathematics should be the preservation of the mathematical component, emphasizing the key ideas on the topic being mastered.

\section{DISCUSSIONS}

In the course of the study, the following results were achieved: students' work on the project aroused genuine interest among students and was more productive than in traditional lessons; in the process of preparing and conducting such lessons, the teacher had the opportunity to form students' new educational skills to independently acquire knowledge and to think over the information found critically; the project method proved to be effective both for solving various small tasks in the form of mini-projects (short-term within a small topic) and for solving difficult to understand issues that require serious preparation over several lessons and involving independent exploratory and research activities; the organization and implementation of projects required sound and prudent guidance and careful planning by the teacher, implying considerable competence in this area (Morris \& Hiebert, 2017); with all its advantages, projects cannot be in each lesson, turning into something every day, the optimal use of this method is as a final lesson on the topic. Summarizing the above, the implementation of the project methodology has a significant prospect in the study of mathematics.

\section{CONCLUSION}

Summing up the theoretical and practical research on the use of the project activity in mathematics lessons, it should be noted that although it is not fundamentally new in teaching practice, it is considered to be the educational technology of the XXI century, as providing the ability to adapt in a rapidly changing world. In terms of this problem, the main task of the teacher is not only giving ready-made knowledge and forming basic skills, but also giving students the opportunity to use and develop the cognitive abilities they already possess (Sang \& Ngampornchai, 2016).

The main result of the introduction of the project activity in teaching mathematics is an obvious increase in the effectiveness of teaching the relevant sections of the school mathematics curriculum, therefore, this method can be one of basic technologies of problem-based learning.

Thus, in modern pedagogy the project activity acquires special significance because it allows to stimulate students' interest through a non-standard approach to the study of material and increases students' motivation to master new knowledge, and also develops creative abilities by making a project product (Palmer, 2016).

This study indicates the effectiveness of project-based learning in teaching mathematics. The materials of the article may be of value for primary and secondary school teachers, teachers of secondary vocational and higher educational institutions. The use of the project activity in teaching mathematics in basic school contributes to increasing the level of motivation to study the most difficult topics of the course, ensures the implementation of an integrated approach to the study of natural sciences.

\section{ACKNOWLEDGEMENTS}

1. The work is performed according to the Russian Government Program of Competitive Growth of Kazan Federal University.

2. The work is performed according to the Program of Development of Federal State-Funded Educational Institution of Higher Education "Financial University under the Government of the Russian Federation" for 2020.

3. The publication has been supported by the 'Russian Academic Excellence Project 5 - 100' of the I M Sechenov First Moscow State Medical University (Sechenov University). 


\section{REFERENCES}

Ambrozy, M., Valčo, M., \& Bhattarai, S. (2017). The Ethical Aspect of Scientific Interest in Selected Physical Theories. Communications - Scientific Letters of the University of Zilina. 19(4), 79-84.

Anderson, N. J. (2017). Thinking Globally, Interviewing Locally: Using an Intensive Interview Project to Teach Globalization and Social Change. Teaching Sociology, 45(4), 388-398. https:/ / doi.org/10.3102/0002831212448095

Aronson, B., \& Laughter, J. (2016). The Theory and Practice of Culturally Relevant Education. Review of Educational Research, 86(1), 163-206. https:/ / doi.org/10.3102/0034654315582066

Atamanova, O. M., Vasilyeva, N. V., Lemeshova, O. P., \& Melehina, A. N. (2018). Criteria for evaluation of student projects. In: Public Lesson. $\quad$ Retrieved $\quad$ on 17.09 .2018 from http:/ / открытыйурок.pф/\%D1\%81\%D1\%82\%D0\%B0\%D1\%-82\%D1\%8C\%D0\%B8/526848/

Celuch, K., Bourdeau, B., \& Smothers, J. (2014). Thinking Innovatively about Teaching Innovation and Ideation: Getting Students to Think Differently. The Journal of Research in Innovative Teaching, 7(1), 27-37.

Christensen, G. (2016). A Poststructuralist View on Student's Project Groups: Possibilities and Limitations. Psychology Learning E Teaching, 15(2), 168-179. https:/ / doi.org/10.1177/1475725716643925

Collings, E. (1926). The experience of the American school on the method of projects. Moscow. New Moscow.

Cowell, J. M. (2017). Student Projects and Publications. The Journal of School Nursing, 33(5), 336-346. https:/ / doi.org/10.1177/1059840517727378

Dewey, J. (2000). Democracy and Education. Trans. with English. Moscow: Pedagogika Press.

Dewey, J., \& Dewey, E. (1922). School of the Future. Berlin: The State Publishing house. RSFSR.

Duke, N. K., Halvorsen, A. L., \& Strachan, S. L. (2016). Project-based learning not just for STEM anymore. Phi Delta Kappan, 98(8), 14-19. https:/ / doi.org/10.1177/0031721716666047

Faleeva, L. V., Bratukhina, E. V., Ezhov, S. G., Gorbunova, L. N., Lopanova, A. P., Viaznikova, L. F., \& Kryukova, N. I. (2017). Student's social experience forming in university vocational training, Eurasian Journal of Analytical Chemistry, 12(7), 1127-1135.

Folomkin, A. I., \& Voronina, M. V. (2017). Educational library for the automation of design calculations springs using Solidworks. Man in India, 97(3), 443-451.

Galushkin, A. (2015). Internet in modern Russia: History of development, place and role. Asian Social Science, 11(18), 305-310.

Gomez-Pablos, V. B., del Pozo, M. M., \& Munoz-Repiso, A. G. V. (2017). Project-based learning (PBL) through the incorporation of digital technologies: An evaluation based on the experience of serving teachers. Computers in Human Behavior, 68(3), 501-512. https:/ / doi.org/10.1016/j.chb.2016.11.056

Heywood, J. (2006). Engineering Education: Research and Development in Curriculum and Instruction. New Jersey: Institute of Electrical and Electronics Engineers. https:/ / doi.org/10.1002/0471744697

Hoa, D. T. K., \& Valco, M. (2018) The philosophy of human rights and the 'political man': Engaging the intellectual legacy of Ho Chi Minh in a technological era. XLinguae, 11(2), 608-624.

Iksanova, T. A. (2015). Project activity at the lessons of mathematics. Actual problems of modern pedagogy: materials VI Intern. sci. Conf. (Ufa, March 2015). Ufa: Summer, pp. 117-120.

Ischenko, G. M. (2015). The use of the project method in classes in higher mathematics. Actual issues of modernization of Russian education, 1, 132-138.

Ivanov, S. V., \& Jordanian, N. N. (1930). New systems of educational work in schools in Europe and North America. Moscow: Educator.

Jurdak, M. (2009). Toward Equity and Social Justice in Mathematics Education. London: Springer Dordrecht Heidelberg. https:/ / doi.org/10.1007/978-1-4419-0558-1

Kai Wah Chua, S., Yin Zhang, Chen, K., Chi Keung Chan, Wing Yi Leea, S., Zou, E., \& Lau, W. (2017). The effectiveness of wikis for project-based learning in different disciplines in higher education. The Internet and Higher Education, 33(4), 49-60. https:/ / doi.org/10.1016/j.iheduc.2017.01.005

Kalashnikov, A. T. (1926). Soviet Labor School: A book for reading and working on the basics of the Soviet system of education. Moscow: An enlightenment worker.

Khan, S. Yu., Bugrahan, Y., Capraro, M. M., \& Capraro, R. M. (2015). In-service Teachers' Implementation and Understanding of STEM Project Based Learning. Eurasia Journal of Mathematics, Science and Technology Education, 11(1), 63-76. https://doi.org/10.12973/eurasia.2015.1306a 
Khusainova, S. V., Matveyeva, L. V., Ermilova, L. P., Yakushevskaya, K. N., Kolomiychenko, L. V., \& Mashkin, N. A. (2018). Adaptive model of psychological and pedagogical accompany of student professional training. Espacios, 39(5), Article number 22.

Kilpatrick, W. H. (1925). Project method. Application of the target setting in the pedagogical process. Leningrad: Brockhaus-Efron.

Kostrova, Yu. S. (2011). The method of projects in the classes on higher mathematics in the context of the competence approach. Young Scientist, 8(2), 114-117.

Laio O. S., Hausmann, R., \& Bezerra, E. A. (2018). On the students' perceptions of the knowledge formation when submitted to a Project-Based Learning environment using web applications. Computers $\mathcal{E}$ Education, 117(2), 16-30. https:// doi.org/10.1016/j.compedu.2017.10.001

Lam, S. F., Wing, Y. I., Cheng, R., \& Choy, H. C. (2010). School support and teacher motivation to implement projectbased learning. Learning and Instruction, 20(6), 487-497. https:/ / doi.org/10.1016/j.learninstruc.2009.07.003

Larson, B., Leung, O., \& Mullane, K. (2017). Tools for Teaching Virtual Teams: A Comparative Resource Review. Management Teaching Review, 2(4), 333-347. https:/ / doi.org/10.1177/2379298117720444

Morris, A. K., \& Hiebert, J. (2017). Toward Effects of Teacher Preparation Courses: Do Graduates Use What They Learned to Plan Mathematics Lessons? American Educational Research Journal, 54(3), 524-567. https:/ / doi.org/10.3102/0002831217695217

Nagel, O. I. (2014). The problem of assessing the project activity of students. Izvestiya ASOU. Scientific Yearbook, 1, 202-211.

Ottmar, E. R., Rimm-Kaufman, S. E., Larsen, R. L., \& Berry, R. Q. (2015). Mathematical Knowledge for Teaching, Standards-Based Mathematics Teaching Practices, and Student Achievement in the Context of the Responsive Classroom Approach. American Educational Research Journal, 52(4), 787-821. https://doi.org/10.3102/0002831215579484

Pakhomova, N. Yu. (2005). Method of the educational project in an educational institution: A manual for teachers and students of pedagogical universities. Moscow: ARCTI. ISBN 5-89415-268-2

Palmer, A. (2016). Is this the tallest building in the world?' A posthuman approach to ethical dilemmas in young children's learning projects. Global Studies of Childhood, 6(3), 283-298. https:/ / doi.org/10.1177/2043610616665035

Pedro, T. S., \& Kinloch, V. (2017). Toward Projects in Humanization. American Educational Research Journal, 54(1), 373-394. https:// doi.org/10.3102/0002831216671210

Polat, E. S., Bukharkina, M. Yu., Moiseeva, M. V., \& Petrov, A. E. (2002). New pedagogical and information technologies in the educational system. Moscow: Academy Publ.

Reid, R., \& Garson, K. (2016). Rethinking Multicultural Group Work as Intercultural Learning. Journal of Studies in International Education, 21(3), 195-212. https:/ / doi.org/10.1177/1028315316662981

Sang, J. L., \& Ngampornchai, A. (2016). Does a case-based online group project increase students' satisfaction with interaction in online courses? Active Learning in Higher Education, 17(3), 249-260. https:/ / doi.org/10.1177/1469787416654800

Shatsky, S. T. (1980). Selected pedagogical compositions. Moscow: Pedagogika.

Shchurkova, N. E. (2005). Pedagogical technology. The second edition, supplemented. Moscow: The Pedagogical Society of Russia.

Sleep, L. (2012). The Work of Steering Instruction toward the Mathematical Point. American Educational Research Journal, 49(5), 935-970. https:/ / doi.org/10.3102/0002831212448095

Tarasova, V. V. (2015). Using the Project Method in Teaching Math. Retrieved on 17.09.2018 from https:// multiurok.ru/files/ispol-zovaniie-mietoda-proiektov-v-obuchienii-matiematikie.html

Tyurikov, A. G., Kosarenko, N. N., Gvozdeva, T. B., Voronina, M. V., Grishnova, E. Y., \& Solovyeva, N. A. (2018). New social reality in the context of information and communication technologies. XLinguae, 11(3), 67-75.

Velieva, S. V., Mashkin, N. A., Khairullina, E. R., Semenova, T. N., Varlamova, M. E., Guseva, T. S., \& Dolgasheva, M. V. (2018). University student professional selfactualization: Context of personality subjectivity. Espacios, 39(20), Article number 12.

Vilenkin, N. Ya., Zhokhov, V. I., Chesnokov, S. I., \& Schwarzburg, A. S. (2013). Mathematics. 6 form. 30th Ed., Moscow: Mnemosina.

Vinogradova, G. A., Akhmadieva, R. S., Konovalova, V. M., Spirina, E. V., Kalugina, O. A., Erdyneeva, K. G., Popova, N. N., \& Mashkin, N. A. (2018). Releasers as factor of student ecological focus formation. Ekoloji, 27(106), 1409-1415. 
Vinogradova, O. S. (2003). Formation of a foreign communicative competence using problematic methods of teaching AI at an advanced stage of a specialized higher education institution: PhD Thesis. Moscow: Russian Academy of Education Institute of General and Secondary Education Publ.

Zamoshnikova, N. N. (2006). The method of projects in teaching mathematics as a means of developing the cognitive interest of younger schoolchildren: PhD Thesis. Chita: Zabaikalsky state Humanitarian and Pedagogical University named after N.G. Chernyshevsky.

\section{http://www.ejmste.com}

